\title{
Improving Student Learning Outcomes Through IT-Based Discovery Learning Class III Elementary School Suggestion Sentence Material
}

\section{Eva Zumroh Rosiana}

SD Negeri Mrisen 1

evarosiana3939@gmail.com

\section{Article History}

received 3/12/2020

\begin{abstract}
This classroom action research aims to improve student learning outcomes for suggestion sentences by implementing an IT-based discovery learning model in class III SD Negeri Mrisen 1, Wonosalam District, Demak Regency, for the 2019/2020 school year. The subjects in this study were third grade students of SD Negeri Mrisen 1 which consisted of 19 students. This research consists of 3 cycles. The instruments used in data collection were observation sheets and formative lesspaper tests in the form of google form. This can be evidenced by the increase in the achievement of students' formative test scores in the first cycle (59.47\%), an increase of $74.21 \%$ in the second cycle and again to $85.79 \%$ in the third cycle. This shows that the application of the IT-based discovery learning learning model at SD Negeri Mrisen 1 can increase the learning outcomes of third grade students by $26.32 \%$ from cycle I to cycle III.
\end{abstract}

Keywords: learning outcomes, discovery learning

\begin{abstract}
Abstrak
Penelitian tindakan kelas ini bertujuan untuk meningkatkan hasil belajar siswa materi kalimat saran dengan penerapan model pembelajaran discovery learning berbasis IT di kelas III SD Negeri Mrisen 1 Kecamatan Wonosalam Kabupaten Demak tahun pelajaran 2019/2020. Subjek dalam penelitian ini adalah siswa kelas III SD Negeri Mrisen 1 yang terdiri dari 19 siswa. Penelitian ini terdiri dari 3 siklus. Instrumen yang digunakan dalam pengumpulan data adalah lembar observasi dan lesspapper tes formatif dalam bentuk google form. Hal itu dapat dibuktikan dengan meningkatnya hasil pencapaian nilai tes formatif siswa pada siklus I $(59,47$ $\%$ ), meningkat $74,21 \%$ pada siklus II serta meningkat lagi menjadi $85,79 \%$ pada siklus III. Hal ini menunjukkan bahwa penerapan model pembelajaran discovery learning berbasis IT di SD Negeri Mrisen 1 dapat meningkatkan hasil belajar siswa kelas III sebesar 26,32 \% dari siklus I ke siklus III.
\end{abstract}

Kata kunci: hasil belajar, pembelajaran penemuan

Social, Humanities, and Education Studies (SHEs): Conference Series https://jurnal.uns.ac.id/shes

p-ISSN 2620-9284

e-ISSN 2620-9292 


\section{PENDAHULUAN}

Menurut Undang-Undang Nomor 32 Tahun 2013 proses pembelajaran pada satuan pendidikan diselenggarakan secara interaktif, inspiratif, menyenangkan, menantang, memotivasi, siswa untuk berpartisipasi aktif, serta memberikan ruang yang cukup bagi prakarsa, kreativitas, dam kemandirian sesuai dengan bakat, minat, dan perkembangan fisik serta psikologis siswa.

Untuk mewujudkan pembelajaran yang interaktif, inspiratif dan menyenangkan maka dibutuhkan metode-metode yang tepat. Alternatif model belajar yang dapat digunakan adalah Discovery Learning berbasis IT (Information Technology). Menurut Hosnan (2014:280) menyatakan bahwa model pembelajaran penemuan (Discovery Learning) merupakan salah satu dari model yang dikembangkan pada kurikulum 2013. Discovery learning adalah proses mental dimana siswa mampu mengasimilasikan suatu konsep atau prinsip. Yang dimaksud dengan proses mental tersebut antara lain yaitu mengamati, mencerna, mengerti, menggolong-golongkan, membuat dugaan, menjelaskan, mengukur, membuat kesimpulan dan sebagainya. (Roestiyah NK, 2012).

Kegiatan pembelajaran menekankan agar siswa terlibat langsung dalam pembelajaran sehingga siswa dapat mengalami dan menemukan sendiri konsepkonsep yang harus ia kuasai. Karena dalam discovery learnig dalam prosesnya menggunakan kegiatan dan pengalaman langsung sehingga akan lebih menarik perhatian anak didik dan memungkinkan pembentukan konsep-konsep abstrak mempunyai makna, serta kegiatannya pun lebih realistis (Ilahi, 2012).

Pada intinya, model pembelajaran Discovery learning ini mengubah kondisi belajar yang pasif menjadi aktif dan kreatif. Mengubah pembelajaran yang teacher oriented di mana guru menjadi pusat informasi menjadi student oriented siswa menjadi subjek aktif belajar ( Agus N Cahyo, 2013).

Adapun langkah-langkah penerapan Discovery Learning menurut Kurniasih, Imas dan Sani (2014:68-71) dalam proses pembelajaran di dalam kelas adalah dengan melakukan beberapa tahapan-tahapan berikut:

1. Stimulation (Stimulasi/Memberikan Rangsangan)

Adapun proses kegiatan yang dilakukan pada tahap pertama ini adalah pendidik memberikan rangsangan kepada siswa dimana nantinya siswa akan melakukan tanya jawab terhadap topik yang disampaikan kemudian dilanjutkan untuk tidak memberi generalisasi. Ini semua dimaksudkan supaya siswa memiliki keinginan sendiri untuk melakukan penyelidikan sendiri. Pada tahapan proses ini guru juga dapat melakukan kegiatan tanya jawab ataupun juga bisa menganjurkan siswa membaca buku untuk memperdalam pemahaman awal mereka dalam memecahkan masalah, disamping juga dapat melakukan aktivitas belajar lainnya yang mengarah pada persiapan pemecahan masalah.

2. Problem Statement (Pernyataan/Identifikasi Masalah)

Setelah melakukan tahapan awal (stimulasi) langkah selanjutnya adalah pendidik memberikan kesempatan kepada siswa untuk melakukan identifikasi terhadap permasalahan yang disajikan sebanyak mungkin, kemudian dilanjutkan dengan menentukan salah satu solusi pemecahan masalah yang dianggap sangat relevan untuk digunakan dalam proses penyelesaian masalah tersebut. Adapun salah satu jenis penyelesaian masalah yang dipilih tersebut digolongkan kedalam kategori hipotesis (pemecahan masalah sementara atas permasalahan yang disajikan). Penyelesaian masalah yang telah dipilih tersebut harus dirumuskan dalam bentuk pertanyaan yakni berupa pernyataan yang berbentuk jawaban sementara dari pertanyaan masalah yang diajukan.

3. Data Collection (Pengumpulan Data)

Ketika proses eksplorasi berlangsung, pendidik juga memberi kesempatan siswa untuk melakukan proses mengumpulkan informasi sebanyak-banyaknya yang 
relevan, ini dimaksudkan untuk memberikan kesempatan kepada siswa dalam membuktikan benar atau tidaknya hipotesis yang telah ditetapkan siswa. Tahap ini berfungsi untuk menjawab pertanyaan atau membuktikan benar tidaknya hipotesis yang telah ditetapkan oleh siswa. Ini berarti bahwa pada tahapan ini, siswa diberi kesempatan untuk mengumpulkan data dari berbagai jenis informasi yang relevan, literature, melakukan proses mengamati objek, melakukan wawancara dengan narasumber tertentu, melakukan eksperimen (uji coba sendiri) dan lain sebagainya.

4. Data Processing (Pengolahan Data)

Pada tahapan ini, semua informasi yang telah didapatkan/dikumpulkan oleh siswa baik dari hasil informasi dari hasil bacaan, melakukan wawancara, melakukan observasi, dan lain sebagainya, lalu semuanya diolah, diacak, diklasifikasikan, ditabulasi, bahkan jika perlu dihitung dengan menggunakan cara-cara tertentu lalu kemudian ditafsirkan pada tingkat kepercayaan tertentu.

5. Verivication (Pembuktian)

Pada tahap ini siswa melakukan pengkajian ulang secara cermat sebagai dasar untuk membuktika benar atau tidaknya hipotesis yang telah ditetapkan tadi dengan temuan alternative, dihubungkan dengan hasil data processing.

6. Generalization (Menarik Kesimpulan/Generalisasi)

Tahap generalisasi/menarik kesimpulan adalah sebuah tahapan yang dilakukan oleh siswa untuk menarik sebuah kesimpulan yang dijadikan sebagai prinsip umum dan berlaku untuk semua masalah kejadian yang sama, dengan tetap memperhatikan hasil verifikasi.

Selain itu penggunaan IT sesuai dengan perkembangan di era teknologi yang semakin maju. Sehingga yang didapatkan siswa tidak hanya peningkatan aktivitas belajar saja akan tetapi hasil belajar siswa juga akan meningkat.

Teknologi informasi merupakan perkembangan sistem informasi dengan menggabungkan antara teknologi komputer dengan telekomunikasi (Baharudin, 2010). Institusi pendidikan di Indonesia mememanfaatkan Teknologi Informasi dan Komunikasi (TIK) untuk pendidikan dengan membangun infrastruktur hardware, jaringan internet, pengadaan sofware dan lain sebagainya, yang semua itu dilakukan dalam usaha memenuhi kebutuhan akan metode pembelajaran yang lebih efektif dan efisien. (Dhilla Viramita Mirza, 2010).

Kelas III SD Negeri Mrisen 1 mempunyai siswa sebanyak 19 orang yang terdiri dari 6 siswa laki-laki dan 13 siswa perempuan. Hasil belajar yang diperoleh siswa kelas III SD Negeri Mrisen 1 adalah sebanyak 14 siswa memperoleh nilai dibawah KKM yaitu 70 dalam bentuk persentase $74 \%$ siswa belum tuntas, sehingga hasil belajar masih rendah. Sedangkan siswa yang tuntas hanya 5 anak dengan bentuk persentase $26 \%$.

Sesuai dengan uraian dalam latar belakang di atas, maka penulis sebagai Guru Kelas III melakukan tindakan dalam pembelajaran dengan rumusan masalah “ Peningkatan Hasil Belajar Siswa melalui Model Discovery Learning Berbasis IT materi Kalimat Saran Kelas III SD “. Penelitian ini bertujuan untuk mengetahui peningkatan hasil belajar siswa melalui Discovery Learning berbasis IT materi kalimat saran kelas III SD Negeri Mrisen 1 Kecamatan Wonosalam Kabupaten Demak.

Pelaksanaan tindakan penelitian ini dilaksanakan dalam tiga siklus. Pada siklus I, penulis menggunakan metode ceramah. Pada siklus II, penulis menggunakan model Discovery Learning dan tampilan slide power point dalam menyampaikan materi pembelajaran. Pada siklus III, penulis menggunakan model Discovery Learning, tampilan slide power point, mengerjakan tes evaluasi melalui Google form via Google Classroom. Dengan penggunaan model Discovery Learning berbasis IT ( Slide power point, Google form dan Google classroom) hasil pembelajaran siswa diharapkan dapat mengalami peningkatan. 


\section{METODE}

Penelitian yang digunakan penulis adalah Penelitian Tindakan Kelas (PTK) yang bertujuan untuk memperbaiki dan mencari solusi dari persoalan yang nyata dan praktis dalam meningkatkan proses pembelajaran di dalam kelas. Subjek Penelitian Tindakan Kelas kali ini adalah siswa kelas III SD Negeri Mrisen 1 yang berjumlah 19 siswa. Tindakan penelitian ini adalah penerapan model Discovery Learning berbasis IT. Waktu pelaksanaan Penelitian Tindakan Kelas akan dilaksanakan pada minggu pertama tanggal 03 bulan Februari tahun 2020, minggu kedua tanggal 10 Februari 2020, dan minggu ketiga tanggal 17 bulan Februari 2020.

Pengumpulan data dilakukan dengan dua cara yaitu Tes dan Non Tes. Data tes diperoleh dari tes tertulis yang diberikan kepada siswa, dan data non tes diperoleh dari observasi. Data diperoleh melalui observasi aktivitas guru dan siswa dikelas. Analisis data adalah proses penghimpunan atau pengumpulan, pemodelan dan transformasi data dengan tujuan untuk menyoroti dan memperoleh informasi yang bermanfaat, memberikan saran, kesimpulan dan mendukung pembuatan keputusan (Widi, 2010). Teknik analisis data menggunakan data kuantitatif yang berupa nilai hasil belajar siswa, dianalisis dengan menggunakan analisis statistik deskriptif.

Prosedur penelitian ini adalah model siklus yang terdiri dari 4 tahap yang saling berkaitan. Empat tahap tersebut adalah perencanaan, tindakan, pengamatan dan refleksi. Dalam setiap siklus dilakukan setiap pertemuan.

\section{HASIL DAN PEMBAHASAN}

Pada kondisi awal ( Siklus I ) peneliti melaksanakan pembelajaran siklus I dengan menggunakan metode ceramah, diskusi, tanya jawab, dan pemberian tugas namun belum mampu memberikan pemahaman konsep materi kalimat saran pada siswa dengan baik. Hal ini dikarenakan metode pembelajaran yang digunakan pada saat siklus I hanya berpusat pada guru sehingga siswa kurang aktif mencari pengetahuan sendiri dan siswa kurang dilibatkan dalam pembelajaran. Siswa mendapat pengetahuan hanya dari guru akibatnya pengetahuan yang diterima kurang bermakna dan pemahaman siswa terhadap konsep tidak optimal.

Hasil perolehan nilai siklus I menunjukkan bahwa siswa yang tuntas belajar hanya 9 anak (47\%) sedangkan siswa yang belum tuntas sebanyak 10 anak (53\%). Nilai rata-rata siswa 59,47 \% dan taraf serap hanya mencapai 59,47 \%.

Siklus II

Berdasarkan analisis data pada kegiatan siklus I yang menunjukkan bahwa masih rendahnya hasil belajar siswa kelas III SD Negeri Mrisen 1 mengenai materi kalimat saran, mendorong penulis untuk mengadakan perbaikan pembelajaran siklus II. Peneliti masih memilih menerapkan model pembelajaran Discovery Learning berbasis IT dalam perbaikan pembelajaran siklus II. Penerapan model pembelajaran Discovery Learning ternyata mampu meningkatkan pemahaman siswa tentang konsep kalimat saran. Hal ini terbukti dengan meningkatnya hasil nilai tes formatif siswa yaitu pencapaian ketuntasan belajar meningkat dari 59,47 \% menjadi 74,21\%. Sedangkan siswa yang belum tuntas menurun dari $53 \%$ menjadi $26 \%$. Nilai rata-rata kelas mengalami kenaikan dari 59,47\% menjadi $74,21 \%$.

Selama pelaksanaan perbaikan pembelajaran siklus II, peneliti juga mengamati aktifitas kinerja siswa dalam melakukan diskusi yang diharapkan siswa mampu mandiri dan menemukan pengetahuan mereka sendiri, aktif menggali informasi dan memberi kebermaknaan pengetahuan mereka untuk digunakan dalam kehidupan sehari-hari mereka.

Tingkat kenaikan hasil belajar antara kegiatan siklus I dan siklus II dapat dilihat pada tabel dan grafik di bawah ini: 
Tabel 1. Tingkat Kenaikan Hasil Belajar Siswa Siklus I dan Siklus II

\begin{tabular}{clccc}
\hline No & Nilai Rata-Rata & $\begin{array}{c}\text { Siklus I } \\
(\%)\end{array}$ & $\begin{array}{c}\text { Siklus II } \\
(\%)\end{array}$ & Keterangan \\
\hline 1 & Tes Formatif & 59,47 & 74,21 & Naik $14,47 \%$ \\
2 & Ketuntasan Belajar & 47 & 74 & Naik $27 \%$ \\
3 & Kinerja Siswa & 69 & 78 & Naik $9 \%$ \\
\hline
\end{tabular}

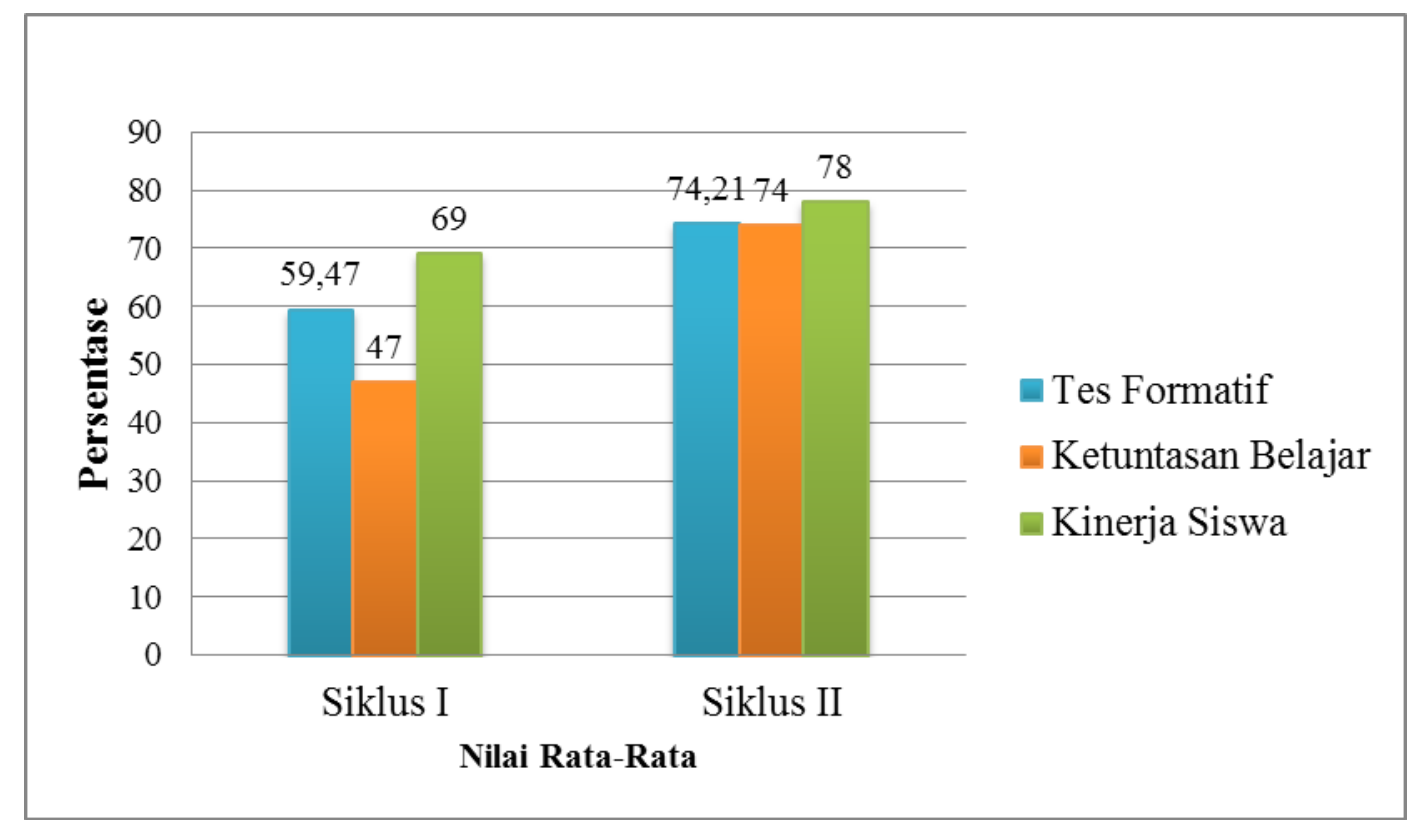

Gambar 1. Perbandingan Hasil Belajar Siklus I dan Siklus II

Siklus III

Pada pelaksanaan perbaikan pembelajaran siklus II telah terjadi kenaikan hasil belajar siswa namun belum sesuai dengan target yang ingin dicapai, oleh karena itu peneliti melakukan refleksi diri terhadap kekurangan pada kegiatan pembelajaran siklus II. Dari hasil refleksi diperoleh gambaran bahwa penerapan model pembelajaran Discovery Learning berbasis IT yang digunakan pada pembelajaran siklus II belum mampu memotivasi siswa untuk meningkatkan pemahaman konsep materi kalimat saran.

Pencapaian nilai kinerja siswa juga belum optimal dikarenakan pada pembelajaran siklus II siswa belum terbiasa dan kurang terampil dalam melakukan diskusi. Untuk menindaklanjuti hasil refleksi pada siklus II, peneliti menyusun skenario pembelajaran (RPP) yang memungkinkan siswa menemukan sendiri pengetahuan mereka. Dengan menerapkan model pembelajaran Discovery learning melalui video pembelajaran serta pembelajaran kontekstual ternyata mampu meningkatkan pemahaman dan motivasi siswa sehingga hasil belajar siswa meningkat.

Peningkatan hasil belajar siswa dapat dilihat pada pencapaian ketuntasan belajar tes formatif dari $74 \%$ menjadi $95 \%$. Siswa yang belum tuntas menurun dari $26 \%$ menjadi $5 \%$. Nilai rata-rata kelas juga mengalami kenaikan dari 74,21\% menjadi $85,79 \%$ sedangkan pencapaian nilai kinerja siswa juga mengalami kenaikan dari $78 \%$ menjadi $90 \%$ di siklus III.

Tingkat kenaikan hasil belajar antara kegiatan siklus II dan siklus III dapat dilihat pada tabel dan grafik di bawah ini:

Tabel 2. Tingkat Kenaikan Hasil Belajar Siswa Siklus II dan Siklus III 
SHEs: Conference Series 3 (4) (2020) 111 - 118

\begin{tabular}{clccc}
\hline No & Nilai Rata-Rata & $\begin{array}{c}\text { Siklus II } \\
(\%)\end{array}$ & $\begin{array}{c}\text { Siklus III } \\
(\%)\end{array}$ & Keterangan \\
\hline 1 & Tes Formatif & 74,21 & 85,79 & Naik 11,58\% \\
2 & Ketuntasan Belajar & 74 & 95 & Naik $21 \%$ \\
3 & Kinerja Siswa & 78 & 90 & Naik $12 \%$ \\
\hline
\end{tabular}

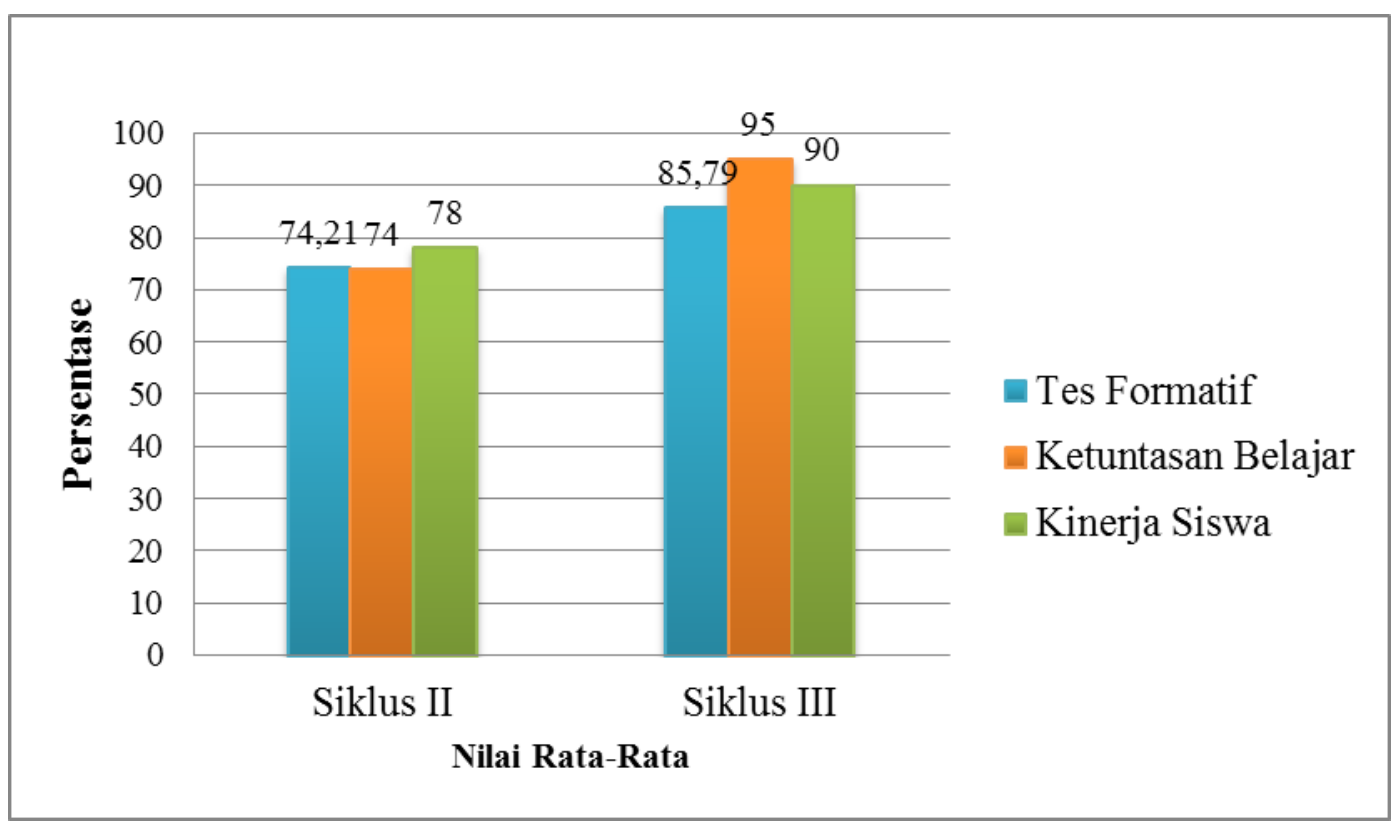

Gambar 2. Perbandingan Hasil Belajar Siklus II dan Siklus III

Korelasi atau hubungan antar siklus dari siklus I, siklus II dan siklus III dapat dilihat pada tabel dan grafik di bawah ini:

Tabel 3. Perbandingan Hasil Belajar Siklus I, Siklus II dan Siklus III

\begin{tabular}{clccc}
\hline No & Nilai Rata-Rata & $\begin{array}{c}\text { Siklus I } \\
(\%)\end{array}$ & $\begin{array}{c}\text { Siklus II } \\
(\%)\end{array}$ & $\begin{array}{c}\text { Siklus III } \\
(\%)\end{array}$ \\
\hline 1 & Tes Formatif & 59,47 & 74,21 & 85,79 \\
2 & Ketuntasan Belajar & 47 & 74 & 95 \\
3 & Kinerja Siswa & 69 & 78 & 90 \\
\hline
\end{tabular}




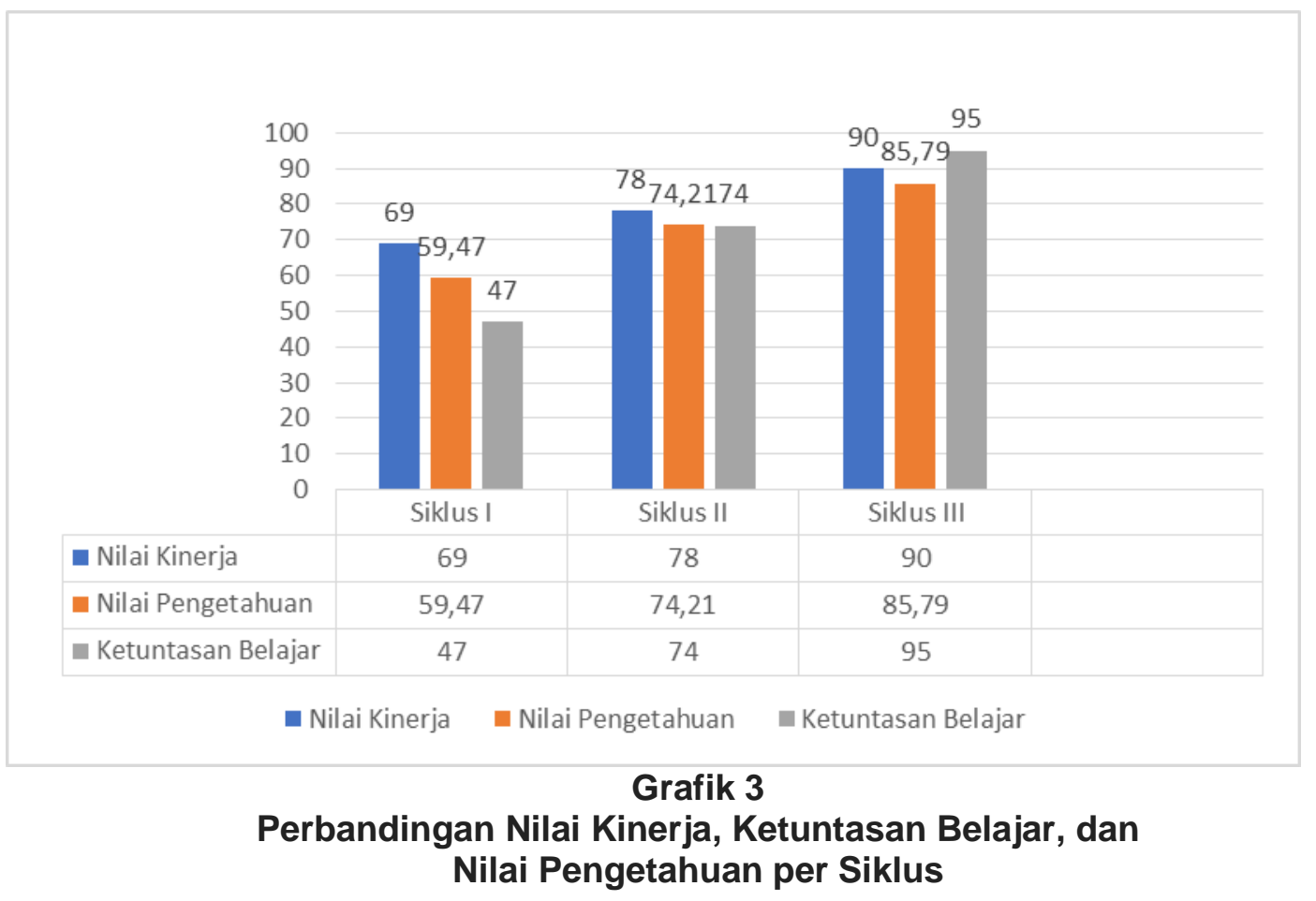

Tabel dan grafik di atas memperlihatkan perbandingan peningkatan hasil belajar yang dicapai siswa pada siklus I, siklus II, dan siklus III pada pembelajaran Tema 4 Kewajiban dan Hakku materi kalimat saran siswa kelas III SD Negeri Mrisen 1 tahun pelajaran 2019/2020 dapat dilihat bahwa nilai rata-rata pencapaian tes formatif, ketuntasan belajar, dan kinerja siswa meningkat dari tiap siklus mulai dari siklus I, siklus II, dan meningkat lagi pada siklus III.

Hasil penelitian ini sejalan dengan penelitian yang dilakukan oleh Endah Setyowati dkk yang menyatakan bahwa Kreativitas Prasiklus siswa kelas V sedang 6 $(27,3 \%)$, rendah $16(72,7 \%)$. siklus I $5(22,7 \%)$ tinggi, $10(45,5 \%)$ sedang, dan 7 $(31,8 \%)$ sangat rendah. Siklus II 4(18\%) sangat tinggi, 9(41\%) tinggi, dan $9(41 \%)$ rendah. Sedangkan hasil belajar siswa prasiklus Bahasa Indonesia 10(46\%). Siklus I $14(64 \%)$ pada siklus II $18(82 \%)$.IPA prasiklus $9(41 \%)$, siklus I $13(59 \%)$, siklus II 18(82\%). SBDP prasiklus 12(54,5\%), siklus I 16(73\%),siklus II 19(86\%). Sedangkan menurut penelitian yang dilakukan oleh Muhammad lqbal Ma'ruf dkk dikatakan bahwa model pembelajaran discovery learning dapat meningkatkan keaktifan dan hasil belajar siswa. Hal ini terbukti dari data yang diperoleh, yaitu meningkatnya keaktifan pra siklus sebesar 15,43 sehingga masuk kategori kurang aktif, setelah dilakukan penelitian pada siklus I, maka rata-rata keaktifan meningkat menjadi 16,90 sehingga berkategori cukup aktif, begitu juga terjadi pada siklus II rata-rata keaktifan mengalami peningkat menjadi 29,50 maka masuk kategori aktif. Data hasil belajar yang didapat juga mengalami peningkatan, pada tahap pra siklus rata-rata hasil belajar siswa 66,44 dengan jumlah 3 siswa tuntas dengan persentase $18,75 \%$ dan tidak tuntas 13 siswa dengan persentase $81,25 \%$. Data siklus I rata-rata hasil belajar siswa mengalami peningkata menjadi 70,93 dengan jumlah 9 siswa tuntas dengan persentase $56,25 \%$ dan tidak tuntas 7 siswa dengan persentase $43,75 \%$. Data siklus II hasil belajar siswa juga mengalami peningkatan menjadi 82,31 dengan jumlah 14 siswa tuntas dengan persentase $87,50 \%$ dan 2 siswa tidak tuntas dengan persentase $12,50 \%$. 
Berdasarkan uraian hasil penelitian dan pembahasan pada penelitian pembelajaran tema 4 kewajiban dan hakku materi kalimat saran siswa kelas III SD Negeri Mrisen 1 tahun pelajaran 2019/2020 dengan menerapkan model pembelajaran discovery learning berbasis IT, maka peneliti dapat menyimpulkan bahwa:

1. Penerapan model pembelajaran discovery learning berbasis IT dapat meningkatkan hasil belajar siswa, dibuktikan dengan peningkatan nilai rata-rata tes formatif siswa dari rata-rata 59,47 di siklus I meningkat menjadi 74,21 di siklus II dan 85,79 pada siklus III.

2. Penerapan model pembelajaran discovery learning berbasis IT efektif dapat meningkatkan pemahaman konsep materi kalimat saran dan menjadikan siswa lebih aktif dalam mengikuti pembelajaran serta memberi pengalaman belajar yang lebih mengesankan bagi siswa.

DAFTAR PUSTAKA

Baharudin, R. (2010). Keefektifan Media Belajar Berbasis Teknologi Informasi Dan Komunikasi. Tadrîs. 5(1).

Cahyo, Agus N . 2013 . Panduan Aplikasi Teori- Teori Belajar Mengajar. Yogyakarta: Diva Press

Hosnan. 2014 . Pendekatan Saintifik dan Kontekstual dalam Pembelajaran Abad ke21. Bogor : Ghalia Indonesia

Ilahi, Mohammad Takdir . 2012. Pembelajaran Discovery Stategi dan Mental Vocational Skill. Yogyakarta : Diva Press

Kurniasih, Imas dan Berlin Sani. 2014. Perancangan Pembelajaran Prosedur Pembuatan RPP yang Sesuai Dengan Kurikulum 2013. Jakarta: Kata Pena.

Ma'ruf, Muhammad Iqbal, Firosalia Kristin, Indri Anugraheni. 2019. Penerapan Model Pembelajaran Discovery Learning untuk Meningkatkan Keaktifan Dan Hasil Belajar Siswa Kelas 4. Jurnal Basic Edu : Vol 3, No 2 . Tersedia pada https://jbasic.org/index.php/basicedu/article/view/7/0

Mirza, Dhilla Viramita . Peran Tekhnologi dalam Dunia Pendidikan. Pendidikan Tatarias dan Kecantikan. Fakultas Pariwisata dan Perhotelan. Universitas Negeri Padang.(file:///C:/Users/lenovo/Downloads/PERAN\%20TEKNOLOGI\%20INFOR MASI\%20DALAM\%20DUNIA\%20PENDIDIKAN.pdf)

Roestiyah N.K. 2012. Strategi Belajar Mengajar. Jakarta: Rineka Cipta.

Setyowati, Endah , Firosalia Kristin, Indri Anugraheni. 2018 . Penggunaan Model Pembelajaran Discovery Learning untuk Meningkatkan Kreativitas dan Hasil Belajar Siswa Kelas 5 Sd Negeri Mangunsari 07. Jurnal Sains \& Teknologi : $\begin{array}{lllll}\text { Vol } & 1 & \text { No } & 1 . & \text { Tersedia }\end{array}$ https://journal.ummat.ac.id/index.php/justek/article/view/408

Widi, Restu Kartiko . 2010. Asas Metodologi Penelitian : Sebuah Pengenalan dan Penuntun Langkah Demi Langkah Pelaksanaan Penelitian. Yogyakarta : Graha IImu 